\title{
The Challenge of Islamic Education and How to Change
}

\author{
Dodi Ilham \\ State Islamic Institute of Palopo (IAIN Palopo), Indonesia \\ *e-mail: dodi@iainpalopo.ac.id
}

\begin{tabular}{l}
\hline \multicolumn{1}{c}{ Article Information } \\
\hline Received: March 20, 2020 \\
Revised: May 12, 2020 \\
Online: June 26, 2020
\end{tabular}

\begin{tabular}{l}
\hline \multicolumn{1}{c}{ Keywords } \\
\hline $\begin{array}{l}\text { Islamic education, the challenge of } \\
\text { change }\end{array}$
\end{tabular}

\begin{abstract}
The realignment of the Islamic education system is not just modification or patchwork. Still, it requires reconstruction, reconciliation, and reorientation so that Islamic education can make a significant contribution to the achievement of the take-off stage. In this paper, the author tries to offer several solutive arguments as well as to become a plan for Islamic education. First, it needs a review of the Islamic education system that is currently running while still promoting the spirit of Islamic teachings. The vision is manifest in the form of an attempt to re-dialogue religious texts against every reality that occurs. Second, prepare more mature and quality human resources armed with comprehensive capabilities. Third, reaffirming the role of all elements in education, namely, individuals, families, communities, educational institutions, and the state. Fourth, to unite Islamic spirituality with science and technology as a strong basis for increasingly pressing challenges, Islamic intellectual tradition, is a hierarchy and interconnection between various scientific disciplines that enable the realization of unity (oneness) in diversity, not just in the realm of faith and religious experience, but also in the world of knowledge.
\end{abstract}

\section{INTRODUCTION}

Correspondingly, the development of the world community in general and Indonesian society, in particular, has entered the information society, which is a continuation of modern society with its characteristics that are rational, future-oriented, open, respecting time, creative, independent and innovative. Whereas information society is reviewed by mastery of information technology, being able to compete, being curious, imaginative, ready to turn challenges into opportunities, and mastering various methods of solving problems (Nata, 2003). In the information society, the role of electronic media plays an important role and even determine the style of life that will affect the mentality and personality of the community. In the information age, the only survivors can survive.

Globalization, as a result of progress in the field of information, has a universal influence, including the environment and society. The public will quickly know various developments and advances in science and technology, such as advances in communication technology, information, and other cultural elements. The world of education must anticipate this trend if you want to place knowledge as an agent of development and development that is not out of date. In this context, experience, as stated by Jusuf Amir Faisal, to prepare human resources not only as recipients of global information flows, but also provide provisions for them to process, adjust and develop everything through the information flow, namely creative, and productive human beings. (Faisal, 1995: 131) Creative and productive human beings must be made into an educational vision, including Islamic education, because such people are coveted for their presence individually, socially, and nationally. 
Education, in essence, is an effort to pass on values that will be a helper and guide of humanity in living life, and at the same time to improve the fate and civilization of humanity. Without education, it believes that humans are no different from past generations of humans when compared to their backwardness, both the quality of life and the process of designing their future. In the extreme, it can even, that the back and forth or excellent or bad civilization of a society, a nation, will be determined by how the education carried out by the nation's community.

Projections of the existence and reality of education, especially Islamic culture, indeed cannot be separating from the past educational process. Islamic school in the early period (the time of the Prophet PBUH), for example, it appears that the effort to inherit values is directed to the fulfillment of human needs to be free from the shackles of heretical creeds adopted by a group of Quraysh. The new idea brought in the education of the Prophet to internalize the values of faith, both individual and collective, to destroy all the jahiliyyah beliefs that existed at that time and considering very auspicious because gradually the form of polytheism, and make monotheism as a moral foundation in human life (Sanaky, 1997).

Terminology of Islamic Studies or Islamic Studies, in the etymological (language) meaning, is a translation of the term Dirasah Islamiyah in Arabic, which in Islamic studies in Europe is called Islamic Studies. Thus, Islamic Studies (Islamic Studies) literally (language) can be stated as "the study of matters relating to Islamic religion", or it can be stated as "an effort to study matters related to Islam". In short, Islamic studies or Islamic studies in language can be interpreted as "the study of matters concerning the religion of Islam". And of course the notion of Islamic Studies or Islamic Studies with this kind of linguistic meaning is still very general, and therefore it is important to take a terminological meaning or term regarding the terms of Islamic Studies or Islamic Studies itself. As for the term (terminology), it is found that there are a number of definitions conveyed by experts on Islamic Studies (Islamic Studies).

The writing team of IAIN Sunan Ampel conveyed the formulation of the definition of Islamic Studies as "a systematic and integrated study to know, understand and analyze in depth matters relating to Islam, both concerning the sources of Islamic teachings, the main points of Islamic teachings, history. Islam, as well as the reality of its implementation in life ". Muhaimin, Abdul Mujib and Mudzakkir expressed their opinion that Islamic Studies is "a conscious and systematic effort to know and understand and discuss in depth about the intricacies or matters relating to Islam, whether related to teachings, history and practices of its implementation. in real terms in everyday life, throughout its history ". Syamsul Arifin, referring to Nur A. Fadhil Lubis, gives the meaning of Islamic Studies as "an attempt to study matters related to Islam through its various empirical forms, as well as its ideal teachings".

Taking into account these definitions, it can be emphasized that Islam is an object or target in Islamic studies. The existence of Islam which is positioned as an object or target of study in Islamic Studies is in its broad meaning, its ideal teachings and its theoretical elaboration and its application in the life of the Muslim community. Based on this brief explanation, it can then be given an affirmation as well as a conclusion that Islamic studies are: "A systematic effort to discuss Islam, both regarding ideal teachings and theoretical elaboration and practical applications in order to obtain a correct understanding of Islam for later practice. ".

In line with the explanation of Islamic Studies above, the following information given by Wandenburg regarding the meaning and scope of Islamic Studies is important to note:

...... Islamic studies includes the study of Islam and the Islamic aspects of Muslim society and culture.... On the basis of the above distinctions, it is possible to identify three different patterns of work that fall into the general space of Islamic Studies. First, in general normative studies of Islam were developed by Muslim scholars to gain knowledge of religious truth (Islam). This study includes religious studies about Islam, such as the interpretation of the Qur'an, hadith science, jurisprudence (fiqih) and Islamic theology (Ilmu Kalam). Usually this study develops in mosques or religious schools (madrasah). Usually, in universities or Islamic institutes in Muslim countries, the above fields are included in the study of shari'ah, the basic science of religion (ushul ad-din). This should be noted because after all, the above normative studies were also cultivated by non-Muslims, such as Christian intellectuals who had withdrawn themselves into the Muslim world or to build a religious theology in a special space defined in Islam. Second, non-normative studies of Islam. Usually, this study is carried out in universities in the form of deeper exploration of what has been studied by Islam so that it becomes a religious teaching in 
Islam and what continues to experience development in Islam so that it becomes something that lives dynamically in the form of factual expression of Muslim religion. Non-normative studies like this are also carried out by both Muslim and non-Muslim intellectuals, where they try to make observations with general rules that exist in scientific research, which is then often called Islamic studies. Third, nonnormative studies on various aspects of Islam related to Muslim culture and society. In a broader scope, this study is not directly related to Islam as a norm. This study takes a fairly broad context, approaching Islam from the point of view of history, literature, or sociology and cultural anthropology, and does not only focus on one perspective, namely religious studies. ...

Based on a number of statements regarding the meaning and scope of Islamic Studies that have been conveyed by these experts, it is possible to convey a final affirmation regarding the existence of three important things related to the existence of Islamic Studies (Islamic Studies). The three important things referred to, related to the existence of Islamic Studies, can be described as follows.

First, considering that Islamic Studies here is a scientific discipline, and each scientific discipline must have a clear object of study, then of course there are objects to be studied in Islamic Studies. Similar to the study (study) of religion which positions "religion" as the target (object) of study or study, the religion of Islam, in its various aspects, is an object discussed in Islamic studies. In this context, Dawam Rahardjo, referring to Bernard Lewis, affirmed that Islamic studies can reveal the existence of three different, but certainly interrelated, things from Islam itself, namely: (1) Islam as a religion or teaching (doctrine), namely as written (spread) in Allah's revelation in the form of the Koran and as-Sunnah. (2) Islam as a theology (and such), as an interpretation of the Koran and as-Sunnah, both textual and contextual. (3) Islam as manifested in various forms of civilization.

Educational development tends to reflect the conditions or needs of the community. Regarding the quality of education in Indonesia, including Islamic teaching, there is a fundamental and general assumption, namely education in Indonesia does not meet current expectations. (Mochtar, 2008: 4-5) The condition of education received a lack of encouragement and judged to have retardation, which led to the weaknesses they experienced.

Seeing this reality, Islamic education in Indonesia needs to get serious attention by efforts to rebuild weaknesses, especially regarding their quality. This necessity, of course, by looking at the relevance and role in the education efforts of the Indonesian nation, which is predominantly Muslim, so that there needs to be a breakthrough such as a change in model and its implementation strategy in dealing with the changing times.

Talking about change can undoubtedly be imagined the occurrence of positive to negative or vice versa from negative to positive, but it is all not easy, of course, will get obstacles and challenges. To find the ideal concept of Islamic education, it is a moral responsibility for every Muslim expert to build Islamic theory as a paradigm of education. Islam, as an educational model, has different characteristics from other models that underlie educational concepts.

\section{METHODS}

The research method used in this study is library research done by collecting articles or scientific papers related to learning planning, learning design, learning model. This research is qualitative, by observing phenomena in Indonesia, formulating problems that occur, and then related to the obtained literature. Data collection techniques are performed by tri-formulating (combined) literature review by collecting data, exceptionally verbal data, through books, articles, notes, and various other scientific literature. The data collected are then analyzed inductively to produce grounded theory, a theory that emerges from non-hypothesis data (Setyosari, 2013). Writing steps to prepare this article: 1) Choosing a problem; 2) a preliminary study; 3) formulating a problem; formulating objectives; 4) conducting a study; 5) making a discussion; 6) formulating conclusions drawn from analysis results and recommendations for other authors.

\section{RESULTS}

Education problems in Indonesia in general, quality, relevance, elitism, and management. Various quantitative indicators are put forward regarding the four problems above, including a comparative analysis comparing the education situation between countries in the Asian region. These four problems 
are significant, fundamental, and multidimensional problems, so that it is difficult to find a solution (Ilham, 2014). This problem occurs in education in general in Indonesia, including Islamic education which is considered to be even more problematic (Arifin, 1991).

Islamic education is also confronted and trapped in the same problem, even if it is observed and then concluded that Islamic education is supported in decline, underdevelopment, helplessness, and poverty, as is experienced by most Muslim countries and communities compared to those who are not Muslim. Let us say, Islamic education is trapped in a never-ending circle, namely the question of quality demands, relevance to needs, changing times, and even education when given "Islamic appendages", is considered to have the connotation of decline and underdevelopment, although now gradually many of them Islamic educational institutions that have shown progress (Soeroyo, 1991: 77). However, Islamic education is seen as always in the second row or marginal position in the national education system in Indonesia. The Law on the national education system states that Islamic education is a sub-system of national education. So the education system is one, namely humanizing humans. However, education has many faces, characteristics, types and levels (family education, schools, communities, Islamic boarding schools, madrasas, diploma programs, high schools, institutions, universities, etc.), and the essence of education is develop human dignity, humanize humans so that they are indeed able to become caliphs (Mastuhu, 1999).

Islamic education is one in the national education system. However, the predicate of backwardness and decline remains attached to it, even Islamic education is often "crowned" only for the benefit of people who are poor or needy, producing people who are exclusive, fanatical, and even at very high levels of behavior. sad that "terrorism-even" is considered to come from Islamic educational institutions, because in fact some Islamic education institutions are "considered" as the place where the group originated. Although this "assumption" is wrong and can be rejected, because there are no Islamic educational institutions that aim to produce or print such groups of people. However, the reality in society is that there is much violent behavior in the name of Islam. Is there something wrong with the system, process and orientation of Islamic education. This is a reality that has been faced by Islamic education institutions in Indonesia. Because of that, there are demands from the community as users of Islamic education so that there are efforts to organize and modernize the system and process of Islamic education so that it becomes quality education, relevant, and able to respond to changes to improve the quality of Indonesian people (Muslim, 2008).

The strategy for developing Islamic education should be selected from the most urgent educational activities, with a central position which will become the essential capital for further structuring and development efforts. Just say, changing paradigms, vision, mission, goals, funds, and arriving at educational programs by the demands of changing life in this country, such as: directed and continuous changes to the educational curriculum in order to keep up with changes in science and technology. (Langgulung, 1980)

The exclusion of Islamic education from competition is actually due to two factors, namely internal and external factors. Internal factors, first, include the management of Islamic education, which in general has not been able to carry out adequate and quality education learning and management. This is reflected in being unable to compete with schools under the guidance of the Ministry of National Education (Kemendiknas) which are generally managed in a modern manner. Second, the professional compensation factor for teachers is still deficient. Teachers, who are the most crucial element in teaching and learning activities, are generally weak in mastery of subject matter, especially regarding general subjects, teaching skills, keles management, and teaching motivation.

This occurs because the Islamic education system is not conducive to the development of teacher professional competence. Third, it is the leadership factor, meaning that there are not a few madrasa heads who do not have a vision and mission for where education will be taken and developed. The head of a madrasa should be a symbol of excellence in leadership, morals, intellectual and professionalism in a formal educational institution, but it is not easy to find in the field of Islamic education. Islamic education leaders not only often cannot build internal communication with teachers, but also weak in communicating with the community, parents, and education users in the interests of providing quality education. Usually the approach used is a bureaucratic approach rather than a professional collegial approach. Managing education is not based on professional considerations, but on a like and dislike approach (Mahfudh Djunaidi, 2005), without having a clear vision and mission. 
The external factors faced by Islamic education are first, the existence of discriminatory treatment by the government against Islamic education. The government has tended to consider and treat Islamic education as a stepchild, especially regarding funds and other matters. Just say, the allocation of funds provided by the government is very different from education within the National Education Ministry (Mahfudh Djunaidi, 2005). So, regardless of all that, whether it is a matter of the Ministry of Religion or the Ministry of National Education, there should not be any gaps in the state budget allocation for Islamic education, after all Islamic education also has a mission to educate the nation, as is the mission carried out by general education. The second factor, it can be said that the bureaucratic paradigm of Islamic education has been dominated by a sectoral approach rather than a functional approach. Islamic education is not considered part of the education sector, because its affairs are not under the Ministry of National Education. Several indicators that show this gap, namely the level of availability of teachers, teacher status, condition of learning rooms, level of student financing [unit cost], to the absence of standardization of the quality of Islamic education, because matters of Islamic education are not under the Ministry of National Education (Abdul Aziz, Kompas, 2005), and more tragically is the discriminatory attitude towards Islamic education products or graduates. The third factor is the existence of community discrimination against Islamic education. Honestly, it must be admitted that the community has tended to be indifferent to the educational process in madrasas or Islamic schools. On average, they view Islamic education as secondary education and usually sending their children to Islamic education institutions is the last alternative after being unable to be admitted to educational institutions within the National Education system (M Dahriman, 2005).

So to get to a quality and superior education, Islamic education should make every effort to fix and restructure its internal problems, such as problems of management, leadership abilities, competence and professional teachers. Classic management education should be abandoned and focus on qualitybased management. Management has a vision, mission, goals and strategies that will be implemented in achieving goals. However, the vision, mission and goals should not only be a pile of planning documents that cannot be realized if we do not have a reasonable and appropriate strategic plan.

\section{The Paradigm of Critical Education in Islamic Education}

The application of the education paradigm in the realm of the teaching and learning process is an essential requirement in achieving the desired educational goals. As explained earlier, the critical education paradigm shares many similarities with the Islamic education paradigm. Islamic education does not necessarily reject any ideas originating from outside Islam. In this case, Islamic culture is not a paradigm that must be contrasted with the secular education paradigm. The critical education paradigm is the paradigm initiated by non-Muslim thinkers, who do not overemphasize aspects of spirituality and faith as the foundation, or in other words, the critical education paradigm is included in the secular education paradigm. However, the learning process that exists in critical education can be used as a methodological reference for Islamic culture in formulating a humanist learning process and can be a means that can support the achievement of educational goals (Sanaky, 1997)

The Islamic education paradigm, also strongly opposes the pattern of liberal or conservative education, which Freire calls the "bank style" education pattern. In the model of Islamic learning, students are not investment suggestions that will be reaping in the future. Design of education to given the standard of Islamic culture, to legitimize and perpetuate an oppressive socio-political and economic structure. However, one thing that needs to be underlining, Islamic education in this discussion, quoting from one of the limitations of Islamic culture, according to Hasan Langgulung, is the education of Muslims and education among Muslims.

Based on the similarity of the principles of learning, Muslim educators can make the patterns of knowledge that exist in the paradigm of critical education as a learning model that will be applied in Islamic culture. According to Omar Muhammad al-Toumy al-Saybany, the method of learning in Islam has several prominent general features, namely:

1. The integration of methods, in terms of objectives tools, with the spirit of teachings and the noble character of Islam.

2. Islamic learning methods are flexible and can accept changes and adjustments according to conditions and atmosphere and follow the nature of students. To accept differences according to the learning of a particular subject, as differences in the level of ability and maturity of students. 
3. The method of learning in Islam earnestly seeks to link between theory and practice or between science and charity.

4. They were throwing out ways to take shortcuts in the learning process.

5. Emphasize the freedom of students to discuss, debate, dialogue within the limits of politeness, and mutual respect. Learners have absolute freedom to express opinions in front of educators and to differ from educators in ideas and thoughts if he has correct evidence and reinforces his stand.

According to Prof. Omar Muhammad al-Toumy al-Saybany, related to the characteristics of the Islamic learning method. Learning methods in Islam have several objectives, namely:

1. They are helping students develop their knowledge, experience, skills, and attitudes.

2. Familiarize students with understanding, healthy thinking, paying attention correctly, observing correctly, being patient, diligent, and conscientious in studying, and encouraging to have the right opinion and be able to throw it boldly and freely.

3. It is creating an atmosphere that is conducive to the learning process.

From the explanation of the characteristics and objectives of the Islamic teaching method above, we can draw a red thread between the learning process in the critical education paradigm and the Islamic education paradigm. As in critical education, in an Islamic school in the learning process, students and educators are both positioned as subjects which together become active actors, while the object of learning is the science that will be studied together.

With the application of the critical education paradigm, we can take inspiration and reference in developing Islamic education. The reality of Muslims today is in a period of decline, due to an error in the Islamic education system. Therefore, the reconstruction of the educational paradigm in Islam, especially in the area of the method of application, is a necessity in advancing Islamic education and civilization.

\section{Method in the Process of Learning Islam}

According to Ahmad Syafi'i Ma'arif, the Eastern world, especially Islam, has long been locked in spiritualism, and the Muslim world has also been "sterile" from significant dynamics. Has a long left the Islamic world in decline to build a new civilization that is far better, according to Muhammad Iqbal, the Muslim world and the West need to connect by marrying "reasoning" and "love." Marriage of these two aspects will give birth to the reasoning that contains the contents of spirituality or enlightened thinking (Baderiah \& Ilham, 2019).

The combination of "reasoning" (intellectual) and "love" (spirituality) is essential in the world of education, as the beginning of the formation of a new world in Islam. In this case, the application of learning methods in Islam that has been carrying out in Islamic education can gift the contents contained with the learning method in the critical education paradigm. According to Omar Muhammad al-Toumy al-Saybany, there are five conventional methods found in the Islamic learning process, namely:

1. Conclusion (deductive) method

2. Comparison method (analogy)

3. Lecture method

4. Discussion method

5. The small group method (halaqah)

We can combine these five learning methods with critical education patterns, which Paulo Freire calls the functional learning method, which consists of three main stages, namely:

1. The codification and decoding stages, namely the elementary education stage in the "theoretical context" and "concrete context." This stage is very similar to the steps of drawing conclusions, comparisons, and lectures in the learning method proposed by Omar Muhammad al-Toumy alSaybany. Codification and decoding methods are stages in the learning process that direct the ability of students to be able to make theoretical conclusions and can make it happen by making comparisons between the findings of the theories obtained as references in the scientific framework. It is also in line with the paradigm of Islamic education adopted by Murtadha Mutahari, that the learning process is a stage to deliver students to be able to make their own decisions directly and be able to make decisions about which is good and acceptable. This stage is expecting to train the independence of Muslim students to be independent in developing the knowledge obtained from 
their teacher. In Muslim societies, there is no more ignorance and blind bigotry that has been exploiting so far and has led to the decline of Muslims.

2. The stage of cultural discussion is advanced in the problematic unit of small working groups. The discussion method and small group that was initiated by Omar Muhammad al-Toumy al-Saybany could be giving critical content contained in the stages of the Paulo Freire cultural discussion. So that from this stage can be produced the problem-solving ability of Muslim students. So that in the context of Muslim society which today is filling with various problems, it can be immediately resolved with the birth of a young generation of Muslims. They have been educating to solve life's challenges faced by Muslims today.

3. The stage of cultural activities, which is the actual praxis stage, in which every action of students both individually and in groups, can be a natural part of reality. Omar Muhammad al-Toumy al-Saybany does not explain this stage, and this stage can be included in the Islamic learning method so that students or young generations of Islam can make practical efforts in improving the conditions of Muslims that occur today. The weakness of Islamic education that happens today is the failure of Islamic Islamic education in giving birth to Muslim "practitioners" who are ready to make constructive changes in their society.

\section{DISCUSSION}

Islamic education, which means an effort to transfer Islamic cultural values to the younger generation, is still faced with dichotomous problems in the education system. Muslim culture is even observing and concluded to be trapped in setbacks, defeats, underdevelopment, helplessness, division, and poverty, as is experienced by most Muslim countries and societies compared to non-Muslims. Education, it is given the frills of Islam, is also considered to connote setbacks and backwardness, although now gradually, many of the Islamic educational institutions have shown progress. The view is very influential on the Islamic education system because the institution always in the position or second row in the constellation of the education system in Indonesia, even though the National Education System Law states that Islamic education is a sub-system of national culture. However, the title of backwardness and setbacks remain attached to it, even Islamic education is not infrequently considered only for the benefit of disadvantaged people.

The same thing was conveyed by Nur A. Fadhil Lubis, that the study or study of Islam covers at least the following three main areas: (1) Islam as a teaching (doctrine), which is manifested in the form of divine revelations collected in the Koran and in the form as-Sunnah, namely the Prophet's guidance for his people who are compiled in the Hadith. In this case, Islamic studies relies on the study of revelation which is manifested in the form of the sources of the Qur'an and Hadith as well as a number of its instruments in the form of the sciences of the Qur'an ('ulum al-Qur'an) and the sciences. Hadith ('ulum alHadits). (2) Furthermore, Islam is also studied as part of a thought, namely as part of fiqh in the "broad" sense, as instructed by Allah SWT in the Qur'an.

In the history of the development of Islamic thought, there are five areas of Islamic thought that are relatively prominent, namely: creed-theology ('ilm al-kalam), law in a broad sense (syari'ah), Islamic philosophy (hikmah /' irfan / philosophy), sufism (tashawwuf), science and technology (science and technology) and Muslim cultural arts are still very minimal studied at Islamic Religious Colleges. (3) Islam at the next level is experience and its application in life. Based on al-Qur'an and as-Sunnah, which were later translated into various thoughts, Islamic teachings were then practiced and applied by Muslims to form an Islamic civilization that has succeeded in illuminating the world for centuries.

Islam as a prominent experience is studied and developed in Islamic Religious Universities - UIN, IAIN, STAIN and other private sectors - is an aspect of education (tarbiyah), da'wah and of course law, while other aspects seem to be neglected. When explained by Amin Abdullah's theory, then Islam as a target or object in Islamic studies or studies, in its diversity of terms or designations, can actually be simplified (simplified) into two categories, namely the dimensions of Islamic normativity or normative Islam and dimensions of historicity of Islam or Islam. historical.

Second, as a conscious and systematic and in-depth effort, the existence of Islamic Studies epistemologically must be built on an epistemological-methodological foundation in the sense that it is carried out by using a certain methodology or approach. In other words it can be stated, in fact the implementation of Islamic Studies, whether carried out by the subject party from the internal Muslim 
community itself (insider) or outsiders from non-Muslim circles or orientalists in general, certainly does not run haphazardly without a methodological framework and or a clear approach, but implemented with a clear methodological framework or approach that can be justified. That is why it is known that there are various approaches presented by experts in the practice of Islamic Studies

Third, as a scientific discipline, Islamic studies or studies, as well as religious studies in general, must be built on a certain axiological foundation or purpose (benefit), and therefore Islamic studies or Islamic studies are of course directed towards achieving that goal or purpose. a certain benefit. Axiologically, Islamic studies, especially for the internal circle of Muslims, are more intended for the purpose of obtaining a deep and correct understanding of Islam in its various aspects, so that later Muslims can carry out and practice it correctly and appropriately.

The reality of Islamic education, in general, is indeed recognized to be experiencing setbacks and underdevelopment, although lately, it has gradually begun to achieve progress. Proven by the increasing number of Islamic educational institutions and several models of education offered. However, the reality of the challenges it faces is still involved, so it demands innovative steps that are expecting to meet as soon as possible. Islamic education is urgent to innovate not only about curriculum and management tools but also operational strategies and tactics so that they are effective and efficient in a pedagogical, sociological, and cultural sense. (Arifin, 1991: 3) Mukti Ali, as quoted by Sanaky, projects that the weaknesses of Islamic education today caused by factors such as weaknesses in the mastery of systems and methods, language as a tool to enrich perceptions and sharpness of interpretation, weaknesses in institutions, as well as the ability of science and technology.

This reality, a constructive solution, is needed to reorganize all components of Islamic education. The realignment of the Islamic education system is not just modification or patchwork. Still, it requires reconstruction, reconciliation, and reorientation so that Islamic culture can make a significant contribution to the achievement of the take-off stage. In this paper, the author tries to offer several solutive arguments as well as to become a plan for Islamic education. First, it needs a review of the Islamic education system that is currently running while still promoting the spirit of Islamic teachings. The vision is the manifestation in the form of an attempt to re-dialogue religious texts against every reality that occurs. Second, prepare more quality human resources armed with comprehensive capabilities. Third, reaffirming the role of all elements in education, namely, individuals, families, communities, educational institutions, and the state. Fourth, to unite Islamic spirituality with science and technology as a strong basis for facing increasingly pressing challenges. Because Islamic intellectual tradition, there is a hierarchy and interconnection between various scientific disciplines that enable the realization of unity (oneness) in diversity, not just in the realm of faith and religious experience, but also in the world of knowledge.

Finding the right level and relationship between various disciplines is the obsession of prominent Islamic intellectuals, from theologians to philosophers, from Sufis to historians, many of whom devote their intellectual energy to the problem of the classification of science. Fifth, build education networks from local, national, and global scale as a form of active communication and information sharing between countries about the development of Islamic education in all parts of the world, so there is no imbalance in the conception of Islamic teaching. Sixth, maintain the local cultural potential of the community as well as a bridge of cultural communication while still holding on to the Islamic spirit. Islamic education must begin to improve itself by developing strategies to be able to meet and be able to answer the challenges of these changes; if not, then Islamic education will be left behind in the global competition. So in developing strategies to solve the problems of change, at least one must pay attention to several characteristics, namely: [a] Islamic education should be more oriented or "more emphasis on the effort of learning [learning] rather than teaching [teaching]." [b] Islamic school can be "organized in a more flexible structure

The term dichotomy of knowledge is merely differentiating or classifying science into religious knowledge and non-religious knowledge, in fact it is not a problem as long as it is not excessive, let alone discriminating against one of the two. The dichotomy of science into religious and non-religious sciences is not new. Islam has had this dichotomy tradition more than a thousand years ago. However, this dichotomy did not cause too many problems in the Islamic education system, until the Western secular education system was introduced to the Islamic world through imperialism. The problem is when the 
dichotomy paradigm of science becomes part of the Muslim perspective which eliminates one of the sciences by classifying high education and low education or the superiority of science and bad science.

In classification, they do distinguish the two, but in principle they are positioned in the same status and position, so that they both get the same portion to be explored, causing a symbiotic-mutualism interaction between the two domains of knowledge. This means that between one another is not an antithesis of the other, but simultaneously becomes a "dual-singular" which contributes to each other.

The views and attitudes of scientists at the time of the Prophet Muhammad SAW, who positioned knowledge in parallel, led to exploration of knowledge other than religious knowledge, although in a very superficial level. Even the prophet Muhammad never taught his faithful and pious followers to stay away from the world which is a medium in reaching the perfection of life. These values were seen when Islam was born in the first half of the 7th century $\mathrm{AD}$, the Arabs were surrounded by nations that had high and magnificent cultures, such as Persia, Rome, Greece, and India. There is already a kind of knowledge which later has influenced the development of Islamic religious knowledge.

Etymologically, the term dichotomy comes from the English dichotomy, which means the division of two parts, bisection, two branches. Whereas in the Big Indonesian Dictionary, the dichotomy is defined as the division in two conflicting groups. Thus, the word dichotomy is using to distinguish or separate two different things.

In terms of terminology, the dichotomy is the separation between science (general) and religion, which then develops into other dichotomic phenomena. A dichotomy is a careful and clear separation of types into two separate from one another where one cannot include in the other and vice versa. So dichotomy is a term used to separate the character of religion and general science as if used separately. Such matter cannot be separating from the historical-cultural background, which in the process of development, there is a boundary between the two domains.

The term dichotomy of science in a variety of different historical literature, and to distinguish the religious sciences from the general sciences many different discourse terms are used, including the words of the afterlife and world sciences, some are calling it syar ' iyyah and science of ghairu syar'iyyah, there are even other names like al-'ulum al-diniyyah and al-'ulum al-'aqliyyah. So basically the term education dichotomy is focused on only two major parts, namely the tanziliyah sciences, namely the sciences developed by human reason related to the values revealed by Allah, both in the book and the hadiths of the Prophet Muhammad, and the sciences - kauniyyah Science, the sciences developed by human reason because of their interaction with nature. In English terms, the difference in words used is known as Islamic Knowledge and Non-Islamic Knowledge. The term dichotomy turns out to have a considerable influence, not only for Islamic education but also for non-Islamic religions, namely other major religions, namely Christianity and Judaism.

Another term for the dichotomy of science that is more dipping in the roots of science is the view of A. Malik Fadjar, who termed the dichotomy with Hellenic for general or modern Science and Semitic for religion. Hellenistic ideas come from classical Greek whose prominent features give a considerable portion to the authority of reason, give priority to rational attitudes and favor secular sciences. Thus, in Greek times the dichotomy of knowledge widened far beyond what it is today.

Another term that was revealed by Harun Nasution in the book Rational Islam that he called the attitude that separates science with the term dualism of science. In polarity, the essential elements of each reality tend to be opposed but do not deny each other; for example, in theology as Harun Nasution's scientific fields exemplify evil and goodness, God and the universe, spirit and body, soul and body, etc.

Of the many terms used in the dichotomy of Islamic education, in general, all names used are conical to the difference between religious and general science, which means that all the existence of science is opposed and separated from one another in a frame of reality that is segmented into subsystems that are each - stand-alone. The consequences of the dichotomy, as mentioned above, will have implications for the alienation of the religious sciences to modernity and keep scientific progress away from spiritual values. If the term dichotomy of science is merely to distinguish it from the purpose of classifying science into religious and non-religious sciences, then the dichotomy becomes ordinary (can be of positive value). However, if the dichotomy of science is to discriminate against one of the sciences, then this will harm each of the sciences.

In the historical process, the dichotomy begins with the development of Islamic-Arabic meetings with other cultures and then continues with the development of educational institutions in Islam and 
ends with the clash of two ways of thinking that are quite influential in the formation of the dichotomy of science in the history of Islamic civilization. Islam, which has initially been universal, accommodated all problems and aspects of life, found a point of division when there was a meeting with philosophical sciences which incidentally originated from non-Islam.

In the context of Islamic education, the dichotomy is better understood as the dualism of the education system between Islamic religious education and general education that separates spiritual awareness and science. The dichotomous education system in Islamic education will cause the breakup of Islamic civilization and will deny the kaffah and universal Islamic culture.

In other words, Islamic Studies, for the internal circle of Muslims, is more intended so that Muslims have a correct and precise understanding of Islam, and then in turn they are able to behave and practice and implement Islam correctly and appropriately. Whereas for non-Muslim outsiders (external), or orientalists in general, the study of Islam is more intended to gain an understanding of the ins and outs of Islam and religious practice among Muslims, it's just for the sake of science or science (Islamology). , and at times not oriented to the interests of being practiced in their daily life. Of course, within certain limits the results of studies or research on Islam carried out by outsiders can also be used by Muslims to conduct studies of Islam in various aspects, especially the empirical dimension of Islam.

Thus, the strategic position of Islamic studies can be said, that through Islamic studies, a complete and comprehensive picture of Islam can be obtained, both in the revelation of the Koran and Hadith as well as in the form of interpretation and application as a human creation of the Ummah. Islam, as an elaboration form of the Koran and al-Hadith.

The urgency of understanding Islam as a whole and comprehensively by means of the revelation of the Koran and al-Hadith on the one hand, and theoretical and practical interpretations or elaborations of it in the form of thought and practical application in the life history of Islamic society, on the other hand, is described by Shari. 'ati, the Iranian historian. In this context, Shari'ati, as explained by Mukti Ali, analogizes the existence of a complete and comprehensive (comprehensive) Islamic religion, as represented in the Koran (also as-Sunnah) and Islamic history, with the totality of the human self, which includes thoughts or intellectual works and their biographies. The point is that an understanding of the religion of Islam that is truly comprehensive and complete (whole and comprehensive), according to Shari'ati, can only be obtained through an understanding of the al-Qur'an (and as-Sunnah) and at the same time the history of Islamic civilization. This is the same as a complete and comprehensive description (description) of one's identity (human), continued Shari'ati, which can only be obtained through an understanding of the overall thought or intellectual work produced as well as its biography.

In general, analyzing and evaluating the logical implications of something on something else is by looking at the conditions before and after something happened. Religious education through madrasas, religious institutes and pesantren is managed by the Ministry of Religion. In contrast, the Ministry of National Education manages general education through primary, secondary and vocational schools and public universities. Islamic education does not merely teach Islamic knowledge theoretically so that it only produces an Islamologist, but Islamic education also emphasizes the formation of Islamic attitudes and behavior in other words forming an Islamist human being. The following are the implications of the education dichotomy:

1. The Ambivalence of the Orientation of Islamic Education

One of the negative impacts of the dichotomy of the education system, especially in Indonesia, is the emergence of an ambivalence in the orientation of Islamic education. [8] Here we can observe, in pesantren education there are still deficiencies in the educational program. For example, education in the muamalah field includes mastery of various disciplines and skills. There is an assumption that all of these are not areas of Islamic work, but secular education. When educational orientation experiences a dichotomy, it will have an impact on the curriculum or material presented. In a material there will be a separation between religious knowledge and non-religious knowledge. So that one of the two will be sidelined and there will be priority.

2. The gap between the Islamic Education System and Islamic Teachings.

The education system which is still ambivalent reflects the dichotomous view that separates the religious sciences from the general sciences. This view contradicts the teachings of Islam itself. Islam has an integralistic teaching which teaches that world affairs are inseparable from matters of the hereafter, but constitute a unity. Therefore, general sciences must be understood as an integral part of 
the religious sciences. Islam does not prohibit us from studying general sciences. For the needs of our life in this world, we also have to study, know, then apply it in our daily life, to help us live in a world that will lead to life in the hereafter.

3. Disintegration of the Islamic Education System

With the existence of the education dichotomy, this will have an impact on the disintegration of the education system, namely the incompatibility and uncertainty of the relationship between general education and religious education. In looking at the two sciences there is no equation in assessing, it is more likely that there will be one of the main goals of an educational institution in carrying out the learning process. So that the two sciences cannot go hand in hand and become a unified whole.

\section{CONCLUSION}

This reality, a constructive solution, is needed to reorganize all components of Islamic education. The realignment of the Islamic education system is not just modification or patchwork. Still, it requires reconstruction, reconciliation, and reorientation so that Islamic culture can make a significant contribution to the achievement of the take-off stage. In this paper, the author tries to offer several solutive arguments as well as to become a plan for Islamic education.

First, it needs a review of the Islamic education system that is currently running while still promoting the spirit of Islamic teachings. The vision is the manifestation in the form of an attempt to redialogue religious texts against every reality that occurs. Second, prepare more mature and quality human resources armed with comprehensive capabilities. Third, reaffirming the role of all elements in education, namely, individuals, families, communities, educational institutions, and the state. Fourth, to unite Islamic spirituality with science and technology as a strong basis for facing increasingly pressing challenges, because, in the Islamic intellectual tradition, there is a hierarchy and interconnection between various scientific disciplines that enable the realization of unity (oneness) in diversity, not just in the realm of faith and religious experience, but also in the world of knowledge. Finding the right level and relationship between various disciplines is the obsession of prominent Islamic intellectuals, from theologians to philosophers, from Sufis to historians, many of whom devote their intellectual energy to the problem of the classification of science. Fifth, build education networks from local, national, and global scale as a form of active communication and information sharing between countries about the development of Islamic education in all parts of the world, so there is no imbalance in the conception of Islamic teaching. Sixth, maintain the local cultural potential of the community as well as a bridge of cultural communication while still holding on to the Islamic spirit.

\section{REFERENCES}

Arifin, H. (1991). Kapita Selekta Pendidikan. Jakarta: PT. Bina Aksara.

Azra, A. (2002). Pendidikan Islam Tradisi dan Modernisasi Menuju Milenium Baru. Jakarta: Logos Wacana Ilmu.

Baderiah, B., \& Ilham, D. (2019). The Implementation Of Pre Marriage Course At KUA Wara Palopo City. IAIN Palopo. http://repository.iainpalopo.ac.id/id/eprint/934/

Faisal, J. A. (1995). Reorientasi Pendidikan Islam. Jakarta: Gema Insani Press.

Ilham, D. (2014). Implementasi Nilai-Nilai Keagamaan pada Mata Pelajaran Umum dalam Upaya Peningkatan Akhlak Peserta Didik di MAN Malili Kabupaten Luwu Timur [Masters, STAIN/ IAIN Palopo]. In IAIN Palopo. http://repository.iainpalopo.ac.id/id/eprint/1145/

Langgulung, H. (1980). Beberapa Pemikiran tentang Pendidikan Islam. Bandung: al-Ma'arif.

Mastuhu. (1999). Memberdayakan Sistem Pendidikan Islam. Jakarta: Logos Wacana Ilmu.

Muslim, K. d. (2008). Paradigma Baru Pendidikan: Restropeksi dan Proyeksi Modernisasi Pendidikan Islam di Indonesia. Jakarta : IISEP.

Nata, A. (2003). Manajemen Pendidikan: Mengatasi Kelemahan Pendidikan Islam di Indonesia, Jakarta: Prenada Media. 
Nur A. Fadhil Lubis, (2000) "Mengembangkan Studi Hukum Islam", dalam Komaruddin Hidayat dan Hendro Prasetyo (ed.), Problem dan Prospek IAIN, Antologi Pendidikan Tinggi Islam. Jakarta: Direktorat Pembinaan Perguruan Tinggi Agama Islam.

Permana, Cecep Eka. (2010) Kearifan Lokal Masyarakat Baduy dalam Mengatasi Bencana. Jakarta: Wedatama Widia Sastra.

Rosidi, Ajip. (2011) Kearifan Lokal dalam Perspektif Budaya Sunda. Bandung: Kiblat Buku Utama..

Sanaky, H. A. (1997). Pendidikan Islam di Indonesia Suatu Kajian Upaya Membangun Masa Depan" Pendidikan Islam dalam Peradaban Industrial. Yogyakarta: Aditya Media.

Sari Mawaddahni, (2017) Filosofi Hidup sebagai Wujud Kearifan Lokal Masyarakat Adat Kasepuhan Sinar Resmi., Local Wisdom Scientific Online Journal 9 (1): 90 -102.

Saiful Muzani (ed.), (1996) Islam Rasional: Pemikiran Keislaman Harun Nasution. Bandung: Mizan.

Shihab, M. Quraish. (2012)Membaca Sirah Nabi Muhammad Saw. dalam Sorotan al-Qur'an dan HadisHadis Shahih. Jakarta: Lentera Hati.

Zamroni. (2000). Paradigma Pendidikan Masa Depan. Yogyakarta: BIGRAF Publishing. 